\title{
MOKSLEIVIŲ SPORTAVIMO IR FIZINIO AKTYVUMO LAISVALAIKIU SĄSAJOS SU SOCIALINIAIS EKONOMINIAIS VEIKSNIAIS
}

\author{
Saulius Šukys ${ }^{1}$, Antanas Bagdonas ${ }^{2}$ \\ Lietuvos kūno kultūros akademija ${ }^{1}$, Kauno švietimo ir ugdymo skyrius ${ }^{2}$, Kaunas, Lietuva
}

Saulius Šukys. Socialinių mokslų daktaras. Lietuvos kūno kultūros akademijos Kinantropologijos ir sporto raidos katedros docentas, Socialinių kūno kultūros ir sporto tyrimų laboratorijos mokslo darbuotojas. Mokslinių tyrimų kryptis — sportuojančių žmonių humaniškos elgsenos ypatumai.

\section{SANTRAUKA}

Tyrimu siekta nustatyti moksleiviu sportavimo ir fizinio aktyvumo sqsajas su socialiniais ekonominiais veiksniais. Tyrimo metu naudotas apklausos raštu metodas. Moksleiviu fizinis aktyvumas vertintas atsižvelgiant i veiklos kryptinguma, t. y. ¿ aktyviq fizinę ir sportine veikla. Šeimos socialinè ekonomine padètis buvo vertinama pagal tèvu isidarbinimo, išsilavinimo rodiklius ir moksleiviu gyvenimo salygas. Atliekant tyrima sudaryta nepriklausoma atsitiktine imtis, reprezentuojanti Kauno miesto šeštos, aštuntos ir vienuoliktos klasès moksleiviu populiacija - 1162 (534 berniukai ir 628 mergaités) Kauno miesto bendrojo lavinimo mokyklu ir gimnaziju moksleiviai. Buvo apklausti 302 šeštos, 342 aštuntos, 284 vienuoliktos klasès bendrojo lavinimo mokyklu ir 234 trečios gimnazijos klasès moksleiviai.

Apklausa neatskleidè sqsaju tarp moksleiviu amžiaus ir sportavimo. Taip pat nenustatytas skirtumas tarp sportuojančiu berniuku ir mergaičiu. Tyrimo duomenimis, vidutiniškai sportuoja penktadalis moksleiviu. Labiau su moksleiviu amžiumi susijęs ju fizinis aktyvumas laisvalaikiu, $t$. y. šeštokai aktyvesni negu vienuoliktokai. Analogiška mažejančio fizinio aktyvumo tendencija su amžiumi išlieka ir pagal lyti, t. y. berniukai yra aktyvesni nei mergaitès šeštose $(p<0,001)$ ir aštuntose $(p<0,01)$ klasése.

Tyrimo duomenimis, moksleiviu sportavimas mažai susijęs su socialiniais ekonominiais veiksniais, t. y. nenustatytas statistiškai reikšmingas skirtumas vertinant sportuojančius moksleivius grupèse tiek pagal tèvu isidarbinimo ir išsilavinimo rodiklius, tiek pagal mokiniu gyvenimo sqlygas. Labiau šeimos statusas lemia moksleiviu fizini aktyvuma laisvalaikiu. Tačiau ši sasaja nevienodai pasireiškia skirtingo amžiaus moksleiviu grupèse. Tyrimo duomenimis, laisvalaikiu fiziškai aktyvesni tie vyresniuju klasiu moksleiviai, kuriu abu tèvai turi aukštají išsilavinima (p $<0,05)$. Tuo tarpu vertinant moksleiviu fizini aktyvuma laisvalaikiu pagal ju gyvenimo salygas išsiskyrè aštuntokai, t. y. aktyvesni geresnes salygas turintys negu prastesnemis gyvenantys $(p<0,01)$. Tyrimas parodè, kad tèvu isidarbinimo rodikliai mažai susiję su moksleiviu fiziniu aktyvumu laisvalaikiu ir nepriklauso nuo ju amžiaus. Todèl tolesniais tyrimais analizuojant fizinio aktyvumo veiksnius reikètu Łvertinti tèvu darbo pobūdị ir jo sqasajas su šeimos pajamomis.

Raktažodžiai: moksleiviu fizinis aktyvumas laisvalaikiu, sportavimas, šeimos socialinis ekonominis statusas.

\section{IVADAS}

$\mathrm{T}$ iek Lietuvos, tiek užsienio mokslininku tyrimais atskleistas teigiamas fizinio aktyvumo poveikis įvairaus amžiaus asmenų fizinei ir psichinei sveikatai. Jų rezultatai rodo, kad fizinis aktyvumas gali padèti išvengti širdies ir kraujagyslių susirgimu, diabeto, nutukimo, osteoporozės, polinkio i depresiją (Jankauskienè ir kt., 2005; Dencker et al., 2006; Raustorp et al., 2006). Pastebèta, kad fiziškai aktyvesni moksleiviai yra aukštesnès savigarbos, turi geresnių socialinès integracijos duomenu (Batutis, Kardelis, 2002), palankesnè jų su sveikata susijusi elgsena: mityba, žalingu ipročių neturèjimas (Zaborskis ir kt., 2005). Nors, anot M. Dencker ir kolegu (2006), kai kurie šių negalavimų, ypač susijusių su fizine sveikata, retai pasireiškia mokyklinio amžiaus tarpsniu, tačiau pakankamo vaikų fizinio aktyvumo skatinimas labai svarbus skiepijant sveikos gyvensenos igūdžius, kurie padètų išvengti tokių neigiamu psichologinių veiksnių kaip nenoras, tin- 
gejjimas, nežinojimas kaip mankštintis ar apskritai neigiamas požiūris į fizinį aktyvumą. Todèl nestebina mokslininkų, medikų ir pedagogų demesys moksleivių fiziniam aktyvumui. Tiriamas jų fizinis aktyvumas ir kaita, analizuojami duomenys lyties aspektu (Grabauskas ir kt., 2004; Vizbaraitè, Petronyte, 2005). Nors tyrimo duomenys (Zaborskis ir kt., 2005) rodo, kad fiziškai aktyvesni moksleiviai sveikiau gyvena negu fiziškai pasyvūs ju bendraamžiai, tačiau moksleivių fizinis aktyvumas šalyje per pastaruosius keletą metų nedidejja. Lietuvos kūno kultūros asociacijos $2005 \mathrm{~m}$. Lietuvos moksleiviu fizinio aktyvumo tyrimo duomenimis, $85,8 \%$ mokiniu yra nepakankamai fiziškai aktyvūs. Nors mokykla ir kūno kultūros pamokos išlieka svarbiausia moksleivių fizini aktyvumą palaikanti ir ugdanti institucija, svarbu įvertinti ir kitus moksleiviu fizinio aktyvumo veiksnius, tiesiogiai nesusijusius su mokykla.

Mokslinèje literatūroje atkreipiamas dėmesys ¿ Ł̌ šeimos (visų pirma tèvų) socialinès ekonominès padèties vaidmeni vaiku požiūriui i sveikatą ir fizini aktyvumą (Kristjansdottir \& Vilhjalmsson, 2001; Huurre et al., 2003; Juškelienè, Kalibatas, 2003; Lawlor et al., 2004; Schnohr et al., 2004 ir kt.). Antai D. Lawlor su bendraautoriais (2004) nustaté, kad tèvų socialinis ekonominis statusas lemia tiek jų pačiuc, tiek vaikų elgseną, susijusią su rūkymu ir fiziniu aktyvumu, ypač paauglysteje. Šie ir kiti (Huurre et al., 2003) autoriai pastebi, kad vaikysteje priklausymas tam tikram socialiniam ekonominiam statusui veikia jų požiūrị i sveiką gyvenseną vèlesniais amžiaus tarpsniais.

Nors socialinę ekonominę padètị, kaip teigiama literatūroje, rodo šeimos pajamos, tėvų išsimokslinimo lygis, gyvenimo sąlygos (turi nuosavą būstą ar ji nuomoja, ar turi automobili, atskirus kambarius visi šeimos nariai ir pan.), prestižas visuomenėje (Kalėdienè ir kt., 1999; Lawlor et al., 2004), tačiau kartais ją vertinant apsiribojama vieno arba abiejų tèvų darbo pobūdžiu ir išsilavinimu (Huurre et al., 2003). Vadinasi, nèra vieningo, moksliškai pagrissto, instrumento socialinei ekonominei padečiai nustatyti. Todèl tyrimai norint išsiaiškinti moksleivių fizinio aktyvumo ir tèvu socialinio ekonominio statuso sąsajas lieka aktualūs, ypač Lietuvoje, kur trūksta panašios analizès. Taigi minètas sąsajas ir bus siekiama atskleisti šiuo tyrimu, kurio tikslas - nustatyti moksleiviu sportavimo ir fizinio aktyvumo laisvalaikiu sąsajas su socialiniais ekonominiais veiksniais.

\section{TYRIMO METODIKA IR KONTINGENTAS}

Tiriamieji. Tiriamają imti sudare reprezentatyvi 1162 moksleiviu grupe (534 berniukai ir 628 mergaitès), tikimybiniu atsitiktiniu būdu parinkta iš Kauno miesto mokyklų. Buvo apklausta 302 šeštos, 342 aštuntos, 284 vienuoliktos klasės bendrojo lavinimo mokyklų ir 234 trečios gimnazijos klasès moksleivių.

Tyrimo metodai. Tyrimo metu buvo taikytas apklausos raštu metodas ir siekta išsiaiškinti moksleivių fizinès veiklos formas pagal kryptingumą, t. y. sportinę veiklą (sporto šakos pratybu lankyma) ir aktyvią fizinę veiklą (žaidimą kieme, važinejjimąsi dviračiu, bėgiojimą, plaukimą ir pan.), kurią galime apibrèžti kaip fizinị aktyvumą laisvalaikiu. Moksleivių sportavimas buvo nustatomas pateikiant klausimą apie tai, ar jie šiuo metu lanko kurios nors sporto šakos pratybas ilgiau nei šešis mėnesius. Atsakymo variantai Taip arba $\mathrm{Ne}$. Fizinis aktyvumas laisvalaikiu buvo vertinamas pagal fizinès veiklos dažnumą per savaitę. Atsakymo variantai: kasdien, 4-6 kartus, 2-3 kartus per savaitę, vieną kartą per savaitę ir nè karto.

Atsižvelgdami i anksčiau minètų autorių tyrimus, šeimos socialinę ekonominę padèti, vertinome pagal tèvų issidarbinimo, išsilavinimo rodiklius ir gyvenimo sąlygas. Vertinant issidarbinimą, moksleivių buvo klausiama, ar jų tėvai turi darbą. Pagal atsakymus išskyrème dvi grupes: pirmą sudarè moksleiviai, kurių abu tèvai turi darbą, antra - kurių vienas ar abu tèvai neturi darbo. Vertinant išsilavinima, moksleiviu buvo klausiama, ar jų tévai yra baigę institutą, universitetą, akademija. Pagal jų atsakymus taip pat išskyrème dvi grupes: pirmą sudarè moksleiviai, kurių abu tevai turi aukštaji išsilavinimą, antrą - tik vienas arba abu neturi tokio išsilavinimo. Analogiškai vertinant gyvenimo sąlygas, moksleivių buvo prašoma nurodyti, ar jie turi atskirą savo kambari, ar namie yra kompiuteris. Turintys kompiuteri ir atskirą kambari buvo priskirti gyvenančiu geresnėmis sąlygomis moksleivių grupei, o neturintys - gyvenančiu prastesnemis sąlygomis.

Tyrimo eiga. Apklausa buvo atliekama pamokų metu prieš tai susitarus su mokyklos direktoriumi ir pasirinktų klasių mokytojais. Laikydamiesi tiriamujų informavimo ir savanoriškumo principų, moksleiviams paaiškindavome tyrimo tikslą, atkreipdavome demesi $i$ tai, kad jie gali atsisakyti dalyvauti, informuodavome, kaip užtikrinsime jų 


\begin{tabular}{|c|c|c|c|c|c|c|c|c|c|c|}
\hline \multirow[t]{4}{*}{$\begin{array}{l}1 \text { lentelè. Skirtingo } \\
\text { amžiaus moksleivių } \\
\text { sportavimo duome- } \\
\text { nys pagal lytị }(\%)\end{array}$} & \multirow[t]{2}{*}{ Sportavimas } & \multicolumn{4}{|c|}{6 klasė $(n=302)$} & \multicolumn{2}{|c|}{8 klasė $(\mathrm{n}=342)$} & \multicolumn{3}{|c|}{$\begin{array}{l}\text { Vienuolikta bendrojo } \\
\text { lavinimo mokyklos ir trečia } \\
\text { gimnazijos klasè }(n=518)\end{array}$} \\
\hline & & \multicolumn{2}{|c|}{$\begin{array}{l}\text { Merginos } \\
(\mathrm{n}=150)\end{array}$} & \multicolumn{2}{|c|}{$\begin{array}{l}\text { Vaikinai } \\
(\mathrm{n}=152)\end{array}$} & $\begin{array}{l}\text { Merginos } \\
(\mathrm{n}=184)\end{array}$ & $\begin{array}{l}\text { Vaikinai } \\
(\mathrm{n}=158)\end{array}$ & \multicolumn{2}{|c|}{$\begin{array}{l}\text { Merginos } \\
(\mathrm{n}=294)\end{array}$} & $\begin{array}{l}\text { Vaikinai } \\
(\mathrm{n}=224)\end{array}$ \\
\hline & \begin{tabular}{|l|} 
Lanko sporto \\
šakos pratybas \\
\end{tabular} & \multicolumn{2}{|l|}{23,3} & \multicolumn{2}{|c|}{18,4} & 18,5 & 17,7 & \multicolumn{2}{|l|}{22,8} & 23,7 \\
\hline & \begin{tabular}{|l|} 
Skirtumas \\
$\chi^{2}(\mathrm{df}), \mathrm{p}$ \\
\end{tabular} & \multicolumn{4}{|c|}{$\chi^{2}=1,10(\mathrm{df}=1), \mathrm{p}>0,05$} & \multicolumn{2}{|c|}{$\chi^{2}=0,03(\mathrm{df}=1), \mathrm{p}>0,05$} & \multicolumn{3}{|c|}{$\chi^{2}=0,05(\mathrm{df}=1), \mathrm{p}>0,05$} \\
\hline \multirow{5}{*}{$\begin{array}{l}2 \text { lentelè. Skirtingo } \\
\text { amžiaus mokslei- } \\
\text { viụ fizinio akty- } \\
\text { vumo laisvalaikiu } \\
\text { duomenys (\%) }\end{array}$} & \multicolumn{8}{|c|}{ Fizinis aktyvumas laisvalaikiu } & \multirow{2}{*}{\multicolumn{2}{|c|}{$\begin{array}{l}\text { Skirtumas } \\
\chi^{2}(\mathrm{df}), \mathrm{p}\end{array}$}} \\
\hline & \multicolumn{3}{|l|}{ Klasės } & \multicolumn{2}{|c|}{\begin{tabular}{|l|} 
Visai \\
nesimankština ar \\
tik kartą per savaitę \\
\end{tabular}} & $\begin{array}{l}\mathrm{Du} \text {-tris } \\
\text { kartus per } \\
\text { savaitę }\end{array}$ & \multicolumn{2}{|c|}{$\begin{array}{l}\text { Keturis_-šešis kartus } \\
\text { per savaitę arba } \\
\text { kiekvieną dieną }\end{array}$} & & \\
\hline & \multicolumn{3}{|l|}{6 klasė $(n=238)$} & \multicolumn{2}{|c|}{6,3} & 44,1 & \multicolumn{2}{|c|}{49,6} & \multicolumn{2}{|c|}{$\begin{array}{l}1-2 \text { gr.: } \chi^{2}=8,67 \\
(\mathrm{df}=2), \mathrm{p}<0,01\end{array}$} \\
\hline & \multicolumn{3}{|l|}{8 klasė $(\mathrm{n}=256)$} & \multicolumn{2}{|c|}{14,1} & 43,8 & \multicolumn{2}{|c|}{42,2} & \multicolumn{2}{|c|}{$\begin{array}{l}1-3 \text { gr.: } \chi^{2}=24,77 \\
(d f=2), p<0,001\end{array}$} \\
\hline & \multicolumn{3}{|c|}{\begin{tabular}{|l} 
Vienuolikta bendrojo \\
lavinimo mokyklos ir trečia \\
gimnazijos klasè $(n=322)$ \\
\end{tabular}} & \multicolumn{2}{|c|}{17,1} & 50,9 & 2,0 & & $(\mathrm{df}=$ & $\begin{array}{l}\text { gr:: } \chi^{2}=6,43 \\
2), p<0,05\end{array}$ \\
\hline $\begin{array}{l}3 \text { lentelè. Skirtingo } \\
\text { amžiaus mokslei- } \\
\text { vių fizinio akty- } \\
\text { vumo laisvalaikiu }\end{array}$ & Fizinis aktyvumas & & & & & $\begin{array}{l}8 \text { klasé } \\
(\mathrm{n}=256)\end{array}$ & & $\begin{array}{l}\text { Vienuc } \\
\text { lavinin } \\
\text { gimna? }\end{array}$ & $\begin{array}{l}\text { no } m \\
\text { zijos }\end{array}$ & $\begin{array}{l}\text { bendrojo } \\
\text { kyklos ir trečia } \\
\text { lasė }(\mathrm{n}=322)\end{array}$ \\
\hline $\begin{array}{l}\text { duomenys pagal } \\
\text { lytị (\%) }\end{array}$ & & & & & $\begin{array}{l}\text { Vaikinai } \\
(\mathrm{n}=121 \\
\end{array}$ & $\begin{array}{l}\text { Merginos } \\
(\mathrm{n}=146)\end{array}$ & $\begin{array}{l}\text { Vaikinai } \\
(\mathrm{n}=110)\end{array}$ & $\begin{array}{l}\text { Mergin } \\
(\mathrm{n}=17\end{array}$ & & $\begin{array}{l}\text { Vaikinai } \\
(\mathrm{n}=143)\end{array}$ \\
\hline & $\begin{array}{l}\text { Visai nesimankštin } \\
\text { kartą per savaitę }\end{array}$ & ar tik & 5,1 & & 7,4 & 18,5 & 8,2 & 20,7 & & 12,6 \\
\hline & $\begin{array}{l}\text { Du-tris kartus pe } \\
\text { savaitę }\end{array}$ & & 59 , & & 29,8 & 46,6 & 40,0 & 50,8 & & 51,0 \\
\hline & $\begin{array}{l}4-6 \text { kartus per sa } \\
\text { arba kiekvieną die }\end{array}$ & & 35 , & & 62,8 & 34,9 & 51,8 & 28,5 & & 36,4 \\
\hline & Skirtumas $\chi^{2}(\mathrm{df})$, & & & & 2), & $\begin{array}{l}\chi^{2}=9,60 \\
p<0,01\end{array}$ & $f=2)$ & $\begin{array}{l}\chi^{2}=4 \\
p>0,0\end{array}$ & $\begin{array}{l}58( \\
5 \\
\end{array}$ & $=2)$, \\
\hline
\end{tabular}

anonimiškumą. Tada moksleiviams buvo paaiškinta, kaip pildyti anketą. I ją atsakyti užtekdavo vienos pamokos. Iš viso buvo išdalytos 1207 anketos. 45 anketos buvo ne visiškai ar netinkamai užpildytos, todèl ị duomenų analizę neitrauktos.

Statistinè analizė. Statistinè tyrimo duomenu analizė atlikta naudojant programų paketą SPSS 13 for Windows. Vertinant apklausos duomenis, buvo apskaičiuojamas procentinis atsakymu $\dot{i}$ klausimus dažnis. Skirtumams tarp grupių nustatyti buvo taikomas chi kvadrato kriterijus. Skirtumo patikimumas laikytas reikšmingu, kai $\mathrm{p}<0,05$.

\section{REZULTATAI}

Tyrimo duomenys parode, kad tik 21,1\% moksleiviu lanko sporto šakos pratybas ilgiau nei pusę metų. Beje, panašus procentas sportuojančiu moksleivių yra visose amžiaus grupėse. Dažniausiai moksleiviai lanko krepšinio $(23,0 \%)$, aerobikos $(16,0 \%)$, sportinių šokių $(14,6 \%)$, plaukimo $(7,0 \%)$, lengvosios atletikos $(5,6 \%)$ ir tinklinio $(4,9 \%)$ pra- tybas. Kitos sporto šakos yra mažiau populiarios. Kadangi buvo tiriami ir berniukai, ir mergaitès, palyginome sportavimo bei fizinio aktyvumo laisvalaikiu duomenis pagal lytį. Sportuojančių berniuku ir mergaičiu skaičius yra panašus visose amžiaus grupèse (žr. 1 lent.). Vertindami moksleivių fizini aktyvumą laisvalaikiu pastebejjome, kad jis su amžiumi stipriai mažèja (žr. 2 lent.). Beje, fizinio aktyvumo laisvalaikiu duomenys su amžiumi skiriasi ir pagal lyti, t. y. berniukai yra aktyvesni nei mergaitės šeštose $(p<0,001)$ ir aštuntose $(p<0,01)$ klasėse (žr. 3 lent.). Analogiška tendencija pastebima ir tarp vyresnių moksleiviu.

Tyrimo duomenimis, moksleiviu sportavimas mažai susijęs su socialiniais ekonominiais veiksniais, t. y. nenustatytas statistiškai reikšmingas skirtumas vertinant sportuojančius moksleivius grupèse tiek pagal tèvų ỉsidarbinimo ir išsilavinimo rodiklius, tiek pagal mokinių gyvenimo sąlygas. Galima ižvelgti tik kai kurias tendencijas: vyresniosiose klasėse daugiau sportuojančių moksleivių, kuriuos priskirtume žemesnio socialinio ekono- 


\begin{tabular}{|c|c|c|c|c|}
\hline \multirow[b]{2}{*}{ Klasès } & \multicolumn{3}{|c|}{ Fizinis aktyvumas laisvalaikiu } & \multirow[b]{2}{*}{$\begin{array}{l}\text { Skirtumas } \\
\chi^{2}(\mathrm{df}), \mathrm{p}\end{array}$} \\
\hline & \begin{tabular}{|l|} 
Visai \\
nesimankština ar \\
tik kartą per savaitę \\
\end{tabular} & \begin{tabular}{|l|}
$2-3$ \\
kartus per \\
savaitę
\end{tabular} & \begin{tabular}{|l|}
$4-6$ kartus per \\
savaitę arba \\
kiekvieną dieną
\end{tabular} & \\
\hline \multicolumn{5}{|l|}{6 klasé } \\
\hline Abu tèvai turi darbą $(n=202)$ & 6,9 & 43,1 & 50,0 & $\chi^{2}=1,0(\mathrm{df}=2)$ \\
\hline Vienas ar abu tèvai neturi darbo $(\mathrm{n}=35)$ & 2,9 & 48,5 & 48,6 & $\mathrm{p}>0,05$ \\
\hline \multicolumn{5}{|l|}{8 klasé } \\
\hline Abu tèvai turi darbą $(\mathrm{n}=228)$ & 14,9 & 43,4 & 41,7 & $\chi^{2}=1,26(d=2)$, \\
\hline Vienas ar abu tèvai neturi darbo $(\mathrm{n}=28)$ & 7,2 & 46,4 & 46,4 & $\mathrm{p}>0,05$ \\
\hline \multicolumn{5}{|l|}{$\begin{array}{l}\text { Vienuolikta bendrojo lavinimo mokyklos } \\
\text { ir trečia gimnazijos klasé }\end{array}$} \\
\hline Abu tèvai turi darbą $(n=255)$ & 16,1 & 49,8 & 31,1 & $\chi^{2}=3,35$ \\
\hline Vienas ar abu tèvai neturi darbo $(\mathrm{n}=66)$ & 21,2 & 56,1 & 22,7 & $(\mathrm{df}=2), \mathrm{p}>0,05$ \\
\hline
\end{tabular}

4 lentelè. Skirtingo amžiaus moksleivių fizinio aktyvumo laisvalaikiu priklausomumas nuo tèvu isidarbinimo rodiklių (\%)

\begin{tabular}{|c|c|c|c|c|c|}
\hline \multirow[b]{2}{*}{ Klasės } & \multicolumn{3}{|c|}{ Fizinis aktyvumas laisvalaikiu } & \multirow[b]{2}{*}{$\begin{array}{l}\text { Skirtumas } \\
\chi^{2}(\mathrm{df}), \mathrm{p}\end{array}$} & \multirow{11}{*}{$\begin{array}{l}5 \text { lentelè. Skir- } \\
\text { tingo a mžiaus } \\
\text { moksleivių fizinio } \\
\text { aktyvumo laisva- } \\
\text { laikiu priklauso- } \\
\text { mumas nuo tėvų } \\
\text { išsilavinimo rodi- } \\
\text { klių (\%) }\end{array}$} \\
\hline & $\begin{array}{l}\text { Visai } \\
\text { nesimankština ar } \\
\text { tik kartą per savaitę }\end{array}$ & $\begin{array}{l}2-3 \\
\text { kartus per } \\
\text { savaitę }\end{array}$ & $\begin{array}{l}4-6 \text { kartus per } \\
\text { savaitę arba } \\
\text { kiekvieną dieną }\end{array}$ & & \\
\hline 6 klasé & & & & & \\
\hline $\begin{array}{l}\text { Abu tèvai turi aukštaji išsilavinimą } \\
(\mathrm{n}=105)\end{array}$ & 4,8 & 40,0 & 55,2 & $\begin{array}{l}\chi^{2}=2,50 \\
(d f=2), p>0,05\end{array}$ & \\
\hline $\begin{array}{l}\text { Abu tèvai neturi ar tik vienas turi } \\
\text { aukštaji išsilavinimą }(n=132)\end{array}$ & 7,6 & 47,0 & 45,4 & & \\
\hline 8 klasé & & & & & \\
\hline $\begin{array}{l}\text { Abu tèvai turi aukštaji išsilavinimą } \\
(\mathrm{n}=121)\end{array}$ & 14,9 & 39,7 & 45,4 & $\begin{array}{l}\chi^{2}=1,71 \\
(d f=2), p>0,05\end{array}$ & \\
\hline $\begin{array}{l}\text { Abu tèvai neturi ar tik vienas turi } \\
\text { aukštaji išsilavinimą }(n=134)\end{array}$ & 13,4 & 47,8 & 38,8 & & \\
\hline $\begin{array}{l}\text { Vienuolikta bendrojo lavinimo moky } \\
\text { ir trečia gimnazijos klase }\end{array}$ & & & & & \\
\hline $\begin{array}{l}\text { Abu tèvai turi aukštaji išsilavinimą } \\
(\mathrm{n}=183)\end{array}$ & 13 , & 50,3 & 36,1 & $\begin{array}{l}\chi^{2}=5,88 \\
(\mathrm{df}=2), \mathrm{p}<0,05\end{array}$ & \\
\hline $\begin{array}{l}\text { Abu tèvai neturi ar tik vienas turi } \\
\text { aukštaji išsilavinimą }(n=136)\end{array}$ & 22,1 & 52,2 & 25,7 & & \\
\hline
\end{tabular}

minio statuso grupei. Priešingos tendencijos nustatytos vertinant moksleivių fizini aktyvumą laisvalaikiu. 4 lentelejje matyti, kad aktyvesni tie vyresniujų klasių moksleiviai, kurių abu tèvai turi darbą. Kita vertus, ši tendencija neišlieka tarp žemesniujų klasių moksleivių. Analogiškai fiziškai aktyvesni tie vyresniujų klasių moksleiviai, kuriu abu tèvai turi aukštaji išsilavinimą, lyginant su bendraamžiais, kurių tèvų išsilavinimas žemesnis $(\mathrm{p}<0,05)$ (žr. 5 lent.). Analogiška tendencija išlieka vertinant fizini aktyvumą ir tarp žemesniuju klasių moksleivių. Vertindami moksleivių fizinio aktyvumo laisvalaikiu duomenis pagal gyvenimo sąlygas, nustatėme statistiškai reikšmingą skirtumą tik tarp aštuntokų, t. y. aktyvesni geresnes sąlygas turintys negu gyvenantys prastesnemis $(p<0,01)$ (žr. 6 lent.). Panašią tendenciją pastebejjome ir tarp vyresnių moksleivių, tačiau ji visai nebūdinga šeštokams.

\section{REZULTATŲ APTARIMAS}

Tyrimas atskleide, kad tik šiek tiek daugiau nei penktadalis moksleivių lanko sporto šakos pratybas. Tai beveik sutampa su kitu tiek Lietuvos, tiek užsienio tyrejjų duomenimis (Kristjansdottir, Vilhjalmsson, 2001; Vizbaraitè, Petronytè, 2005). Kaip ir kiti autoriai (Narring et al., 1999; Kristjansdottir, Vilhjalmsson, 2001), taip ir mes pastebejome, kad moksleivių fizinis aktyvumas laisvalaikiu su amžiumi linkęs mažèti. Tačiau tokia tendencija neišryškejja vertinant skirtingo amžiaus moksleivių sportavimą. Nustatytas skirtumas tarp berniukų ir mergaičiu fizinio aktyvumo laisvalaikiu sutampa su kitų tiek Lietuvos (Grabauskas ir kt., 2004), tiek užsienio autorių tyrimo duomenimis (Narring et al., 1999; Kristjansdottir, Vilhjalmsson, 2001; Godin, 2005). Nenustatyta skirtumo vertinant 


\begin{tabular}{|c|c|c|c|c|c|}
\hline \multirow{5}{*}{$\begin{array}{l}6 \text { lentelè. Skir- } \\
\text { tingo amžiaus } \\
\text { moksleivių fi- } \\
\text { zino aktyvumo } \\
\text { laisvalaikiu pri- } \\
\text { klausomumas } \\
\text { nuo gyvenimo } \\
\text { sąlygų (\%) }\end{array}$} & \multirow[b]{2}{*}{ Klasès } & \multicolumn{3}{|c|}{ Fizinis aktyvumas laisvalaikiu } & \multirow[b]{2}{*}{$\begin{array}{l}\text { Skirtumas } \\
\chi^{2}(\mathrm{df}), \mathrm{p}\end{array}$} \\
\hline & & $\begin{array}{l}\text { Visai } \\
\text { nesimankština ar } \\
\text { tik kartą per savaitę }\end{array}$ & $\begin{array}{l}2-3 \\
\text { kartus per } \\
\text { savaitę }\end{array}$ & $\begin{array}{l}4-6 \text { kartus per } \\
\text { savaitę arba } \\
\text { kiekvieną dieną }\end{array}$ & \\
\hline & $\begin{array}{l}6 \text { klase } \\
\text { Turi geresnes gyvenimo sąlygas }(\mathrm{n}=133) \\
\text { Turi prastesnes gyvenimo sąlygas } \\
(\mathrm{n}=105)\end{array}$ & $\begin{array}{l}6,0 \\
6,6\end{array}$ & $\begin{array}{l}42,1 \\
46,7\end{array}$ & $\begin{array}{l}51,9 \\
46,7\end{array}$ & $\begin{array}{l}\chi^{2}=0,64 \\
(d f=2), p>0,05\end{array}$ \\
\hline & $\begin{array}{l}8 \text { klase } \\
\text { Turi geresnes gyvenimo sąlygas }(n=166) \\
\text { Turi prastesnes gyvenimo salygas }(n=90)\end{array}$ & $\begin{array}{l}11,4 \\
18,9\end{array}$ & $\begin{array}{l}39,2 \\
52,2\end{array}$ & $\begin{array}{l}49,4 \\
28,9\end{array}$ & $\begin{array}{l}\chi^{2}=10,34 \\
(d f=2), p<0,01\end{array}$ \\
\hline & $\begin{array}{l}\text { Vienuolikta bendrojo lavinimo mokyklos ir } \\
\text { trečia gimnazijos klasé } \\
\text { Turi geresnes gyvenimo sąlygas }(\mathrm{n}=212) \\
\text { Turi prastesnes gyvenimo sąlygas } \\
(\mathrm{n}=109)\end{array}$ & $\begin{array}{l}15,6 \\
20,2\end{array}$ & $\begin{array}{l}49,5 \\
54,1\end{array}$ & $\begin{array}{l}34,9 \\
25,7\end{array}$ & $\begin{array}{l}\chi^{2}=3,12 \\
(d f=2), p>0,05\end{array}$ \\
\hline
\end{tabular}

sportavimo duomenis pagal lyti. Reikia pažymėti, kad kiti tyrejjai ne visada apskritai išskiria fizini aktyvumą laisvalaikiu ir sportavimą. $\mathrm{O}$ vertinant šias fizinès veiklos formas yra nustatyta, kad berniukai daugiau sportuoja negu mergaitès (Kristjansdottir, Vilhjalmsson, 2001).

Analizuojant sąsajas tarp moksleivių fizinio aktyvumo ir šeimos socialinio ekonominio statuso, verta atkreipti dėmesi i veiklos kryptinguma, t. y. i sportavimą ir fizini aktyvumą laisvalaikiu. Mūsu apklausa parodè, kad aukštesnis šeimos socialinis ekonominis statusas nėra veiksnys, labiau skatinantys moksleivių sportavimą. Tyrimo metu išryškèjo netgi priešinga tendencija — daugiau sportuoja tokių šeimų moksleiviai, kurių tèvai neturi aukštojo išsilavinimo ar darbo. Beje, analogiškai daugiau tokių šeimų vaikų ateityje planuoja pradèti kultivuoti pasirinktą sporto šaką. Tokias tendencijas gali lemti vis dar egzistuojančios galimybès lankyti kai kurių sporto šaku pratybas nemokamai (pvz., berniukai - futbolo, mergaitès - mokyklose aerobika). Jeigu tèvai yra mažiau pasiturintys, jų vaikams tai gali būti viena iš nedaugelio alternatyvų tobulinti gebejjimus patinkamoje veikloje, aktyviai praleisti laisvalaiki. Labiau pasiturinčių šeimų vaikai gali pasirinkti įvairesnes (kartu fiziškai aktyvias) laisvalaikio praleidimo formas. Tai, kad jie dažniau negu bendraamžiai, atstovaujantys žemesnio socialinio statuso šeimoms, renkasi aktyvias laisvalaikio praleidimo formas, galima spręsti iš kai kurių apklausos duomenų. Laisvalaikiu fiziškai aktyvesnių daugiau tarp tų moksleivių, kurių abu tèvai turi aukštaji išsilavinimą ir tarp gyvenančių geresnemis sąlygomis. Kiek mažiau aktyvią veiklą laisvalaikiu galètume sieti su tėvo ar motinos darbo turèjimu. Pastarojo veiksnio mažesnè sąsaja su vai- kų fiziniu aktyvumu, matyt, yra dèsninga, nes darbo rinkoje trūksta darbo jègos, nors bedarbystè gali būti laikinas reiškinys. Na, o analizuojant išsilavinimą ir gyvenimo sąlygas, to pasakyti negalima. Nors aukštasis išsilavinimas gali būti prieinamas daugeliui norinčiu ji igyti, tačiau tam reikia laiko, noro, o kartais ir finansu. Tą pati galima pasakyti ir apie gyvenimo sallygas, kurias reikia susikurti, o tai leidžia geriau apmokamas darbas, dažnai ir prestižiškesnis, neretai priklausantis nuo turimų žinių, kurios vèlgi sietinos su aukštuoju išsilavinimu. Beje, literatūroje dažnai rašoma, kad šeimos socialinis ekonominis statusas turi įtakos ne tik šeimos nariu fiziniam aktyvumui, bet ir sveikatai (Juškienè, Kalibatas, 2003; Lawlor et al., 2004). Tokie socialinio ekonominio statuso komponentai kaip šeimos pajamos lemia ne tik galimybę rinktis ivairias aktyvias laisvalaikio praleidimo formas, bet ir sveikesni maistą, geresnes gyvenimo sąlygas.

Vertinant apklausos duomenis reikètu atkreipti dèmesi i kai kuriuos tyrimo metodologinius aspektus, kurie gali būti aktualūs atliekant tolesnius tyrimus. Visų pirma galima svarstyti, ar pasirinkti socialinio ekonominio statuso komponentai yra pakankami, ar nereikètu jų praplèsti, o gal kai kurių visai atsisakyti. Manome, kad tiriant vyresniojo amžiaus moksleivius reikètų išsiaiškinti tèvų darbo pobūdi, neapsiribojant faktu, dirba jie ar ne. Atliktos apklausos metu toks klausimas taip pat buvo pateiktas, tačiau vèlesnè duomenų analizė atskleidè: i ji žemesniujų klasių moksleiviams atsakyti sudėtinga. Todèl paminètas socialinio ekonominio statuso komponentas svarbesnis tiriant vyresniojo amžiaus moksleivius. Reikètu atkreipti demesi $\mathfrak{i}$ H. Schroder ir bendraautoriu (2004) išsakytą mintị, kad svarbiausi komponen- 
tai, leidžiantys spręsti apie socialinį ekonomini asmens statusą, yra darbo pobūdis, pajamos ir išsilavinimas (pastarasis, autorių nuomone, yra bene svarbiausias), tačiau jie nebūtinai visada gali būti susiję su fiziniu aktyvumu. Pirmiausia taip teigti autorius paskatino jų pačių tyrimo duomenys, kurie neatskleidè ryškesnių išsilavinimo ir fizinio aktyvumo sąsajų. Antra, tyrejai atkreipia demesi, kad ieškant socialinio ekonominio statuso ir sveikos gyvensenos sąsajų (tarp jų ir fizinio aktyvumo) reikia atsižvelgti $i$ tyrimo kontekstą, ivvertinti socialines ekonomines salygas, taip pat egzistuojančias tradicijas. Būtent pastaraji veiksni autoriai iškèlè analizuodami savo tyrimo duomenis. Kartu egzistuoja ir bendri dèsningumai, pavyzdžiui, naujų technologijų diegimas, kuris dažniausiai neigiamai veikia moksleivių fizini aktyvumą laisvalaikiu (Narring et al., 1999). Tai atskleidžia R. Motl su kolegomis (2006) atlikto tyrimo rezultatai — kuo mažiau moksleiviai žiūri televizorių ar žaidžia kompiuterinius žaidimus, tuo fiziškai aktyvesni yra laisvalaikiu, ir atvirkščiai. Beje, toks neigiamas priežastinis ryšys visai nepriklauso nuo tèvų socialinio ekonominio statuso.

Atlikta tévų socialinio ekonominio statuso sąsajų su vaikų sportavimu bei fiziniu aktyvumu laisvalaikiu analizè leidžia numatyti ir tolesniu tyrimu perspektyvas. Atliekant juos, reikètų atsižvelgti i anksčiau išsakytas pastabas dèl tèvu darbinès veiklos vertinimo. Verta atkreipti dèmesi ir i patị tyrimo pobūdi, tiksliau - $\mathfrak{i}$ sportavimo ir fizinio aktyvumo laisvalaikiu ivvertinimą. Pastaraisiais metais kai kurie mokslininkai (Dencker et al., 2006) abejoja, ar klausimynas yra patikima duomenų apie fizinį aktyvumą rinkimo priemonè, tiksliau - abejojama klausimynu patikimumu vertinant fizini aktyvumą, o ne sportavimą. Todèl natūralu, kad taikomos ir kitos aktyvumo vertinimo priemonès, pavyzdžiui, akcelerometrai. Deja, tie patys autoriai kritiškai vertina ir pastaruosius. Viena vertus, jie kur kas tiksliau gali įvertinti tiriamojo fizini aktyvumą, tačiau duomenų patikimumą daugiau lemia tai, kiek pats tiriamasis bus motyvuotas tokiam tyrimui. Todèl vienareikšmiškai teigti, kad ateityje reikètų visai atsisakyti klausimynų, negalima. Pagaliau jie vis vien išlieka pagrindine priemone norint surinkti informacija apie tuos tiriamo dalyko kintamuosius, kurių negalima sužinoti kitomis priemonėmis.

\section{IŠVADOS}

1. Apklausos duomenimis, sportuojančių skaičius su amžiumi nekinta. Vidutiniškai sportuoja penktadalis moksleivių. Kur kas labiau su moksleivių amžiumi susijęs jų fizinis aktyvumas laisvalaikiu, t. y. šeštokai kur kas aktyvesni nei vienuoliktokai. Analogiška tendencija nustatyta ir pagal moksleivių lyti.

2. Šeimos socialinis ekonominis statusas mažai turi itakos moksleiviu sportavimui. Kur kas labiau šeimos statusas lemia moksleivių fizini aktyvumą laisvalaikiu. Nustatyta, kad laisvalaikiu yra aktyvesni tie moksleiviai, kurie priskirtini aukštesnio socialinio ekonominio statuso šeimoms.

3. Moksleiviu fizinis aktyvumas laisvalaikiu labiau susijęs su tokiais šeimos socialinį ekonomini statusą lemiančiais veiksniais kaip išsilavinimas ir gyvenimo sąlygos.

\section{LITERATŪRA}

Batutis, O., Kardelis, K. (2002). Moksleivių socialinès izoliacijos, integracijos ir savigarbos sąsaja su fiziniu aktyvumu. Ugdymas. Küno kultūra. Sportas, 2 (43), $10-16$.

Dencker, M. et al. (2006). Daily physical activity in Swedish children aged 8-11 years. Scandinavian Journal of Medicine \& Science in Sports, 16 (4), 252-257.

Godin, G. (2005). Identifying factors associated with regular physical activity in leisure time among Canadian adolescents. American Journal of Health Promotion, 20 (1), 20-27.

Grabauskas, V., Zaborskis, A., Klumbienè, J., Petkevičienè, J., Žemaitienè, N. (2004). Lietuvos paaugliu ir suaugusių žmonių gyvensenos pokyčiai 1994-2002 metais. Medicina, 40 (9), 884-890.

Huurre, T., Aro, H., Rahkonen, O. (2003). Well-being and health behaviour by parental socioeconomic status. A follow-up study of adolescents aged 16 until age 32 years. Social Psychiatry \& Psychiatric Epidemiology, $38,249-255$.

Jankauskienè, R., Pajaujienè, S., Kairaitis, R. (2005). Laisvalaikiu sportuojančiu moteru savo svorio vertinimo adekvatumas amžiaus, sportavimo trukmès ir kūno masės aspektais. Visuomenes sveikata, 2 (29), 53-57.

Juškelienė, V., Kalibatas, J. (2003). Psichosocialiniai veiksniai, turintys itakos paaugliu sveikatai. Visuomenès sveikata, 4 (23), 5-12.

Kalèdienė, R., Petrauskienè, J., Rimpela, A. (1999). Šiuolaikinés visuomenés sveikatos mokslo teorija ir praktika. Kaunas: Šviesa.

Kristjansdottir, G., Vilhjalmsson, R. (2001). Sociodemographic differences in patterns of sedentary and physically active behavior in older children and adolescents. Acta Paediatrica, 90, 429-435.

Lawlor, D. A., Smith, G. D., Ebrahim, S. (2004). Association between childhood socioeconomic status and coronary he- 
art disease risk among postmenopausal women: Findings from the British women's heart and health study. American Journal of Public Health, 94 (8), 1386-1392.

Motl, R., McAuley, E., Birnbaum, A., Lytle, L. (2006). Naturally occuring changes in time spent watching television are inversely related to frequency of physical activity during early adolescence. Journal of Adolescence, 29 (1), 19-32.

Narring, F., Caucleray, M., Cavadini, C., Michaud, P. (1999). Physical fitness and sport activity of children and adolescents: Methodological aspects of a regional survey. Sozial und Praventivmedizin, 44, 44-54.

Raustorp, A., Mattsson, E., Svensson, K., Stahle, A. (2006). Physical activity, body composition and physical self-esteem: A 3-year follow-up study among adolescents in Sweden. Scandinavian Journal of Medicine \& Science in Sports, 16 (4), 258-266.

Schnohr, Ch., Mojbjerre, L., Riegels, A. et al. (2004). Does educational level influence the effects of smoking, alcohol, physical activity, and obesity on mortality? A prospective population study. Scandinavian Journal of Public Health, 32, 250-256.

Schroder, H., Marrugat, J., Schmelz, E., Rohlfs, I. (2004). Relationship of socioeconimic status with cardiovascular risk factors and lifestyle in a Mediterranean population. European Journal of Nutrition, 43, 77-85.

Vizbaraite, D., Petronyte, G. (2005). Paauglių fizinio aktyvumo kaitos analizè lyties ir sveikatos aspektu. Sporto mokslas, 2 (40), 77-80.

Zaborskis, A., Lenčiauskienè, I., Klibavičius, A. (2005). Sveikatos stiprinimas mokykloje ir moksleiviu gyvensena. Visuomenés sveikata, 2 (29), 34-40.

\title{
LINKS OF PUPILS' SPORTS AND PHYSICAL ACTIVITY AT THEIR LEISURE TIME WITH SOCIAL ECONOMIC FACTORS
}

\author{
Saulius Šukys ${ }^{1}$, Antanas Bagdonas ${ }^{2}$ \\ Lithuanian Academy of Physical Education ${ }^{I}$, Education and Training Division of Kaunas Municipality ${ }^{2}$, \\ Kaunas, Lithuania
}

\begin{abstract}
The aim of the study was to establish the links of pupils' sports and physical activity with their social economic factors. Pupils' physical activity and the social economic factors of their families were established using a questionnaire. Physical activity of pupils was evaluated in regard to the singleness of their activities, i. e. active participation in physical activities and sports. Social economic situations of families were judged by parents' jobs, education and pupils' living conditions. The independent random sample of the research represented the population of the pupils from the sixth, the eighth and the eleventh grades in Kaunas schools. It consisted of 1162 (534 boys and 628 girls) schoolchildren from Kaunas secondary schools and gymnasiums: 302 pupils from the sixth grades, 342 from the eighth grades, 284 from the eleventh grades and 234 gymnasium third year pupils.

The questionnaire survey did not reveal any considerable links between pupils' age and their participation in sports. There were no differences of the participation in sports between the girls and the boys, either. According to the research data only about one fifth of pupils were engaged in sports. Pupils' age was more linked to their leisure activities, i. e. the sixth grade pupils were more active than the eleventh grade pupils. Analogical decreasing tendency of physical activity with age remained comparing the pupils by gender, i. e. boys were more active in their leisure time activities than girls in the sixth $(\mathrm{p}<0.001)$ and the eighth $(\mathrm{p}<0.01)$ grades.

The social economic status of families had little influence on pupils' participation in sports. There were no statistical differences between pupils' participation in sport and their parents' occupation, education and living conditions, but the family status conditioned pupils' physical activity at their leisure time. However, this relationship was diverse in different age groups. It was established that the eleventh grade students whose both parents had higher education were more physically active at their leisure time $(p<0.05)$. But if we compare pupils' physical activity at the leisure time to their living conditions, we see that the eighth grade students were different, i. e. better-off students were more active than their peers who were hard up $(p<0.01)$. Research results showed that the occupation of pupils' parents had weak relation to their physical activity regardless of their age. Thus, we could conclude that in the future studies we should evaluate parents' occupation and its relation with family income when we analyze factors related to pupils' physical activity at their leisure time.
\end{abstract}

Keywords: pupils' physical activity at their leisure time, participation in sports, social economic status of family.

Gauta 2006 m. lapkričio 27 d.

Received on November 27, 2006

Priimta $2007 \mathrm{~m}$. vasario $13 \mathrm{~d}$.

Accepted on February 13, 2007
Saulius Šukys

Lietuvos kūno kultūros akademija

(Lithuanian Academy of Physical Education)

Sporto g. 6, LT-44221 Kaunas

Lietuva (Lithuania)

Tel +370 37302637

E-mailsml.saulius@mail.1t 